\title{
GERMINATION OF CACTUS SEEDS UNDER SALINE STRESS ${ }^{1}$
}

\author{
JOÃO HENRIQUE CONSTANTINO SALES SILVA, GILVANEIDE ALVES DE AZERÊDO
}

\begin{abstract}
Cactus seeds in seasonal dry tropical forests are subject to several stressors, such as salt stress which limits imbibition and therefore germination. Thus, this study aimed to compare germination performance of Cereus jamacaru subsp. jamacaru and Pilosocereus pachycladus subsp. pernambucoensis seeds under salinity conditions. To this end, $\mathrm{NaCl}$ and $\mathrm{KCl}$ solutions were used in the following osmotic potentials: 0.0 (control), $-0.2,-0.4,-0.6,-0.8,-1.0$, and $-1.2 \mathrm{MPa}$. Seeds were placed to germinate at $25{ }^{\circ} \mathrm{C}$ and 12 -hour photoperiod. The number of germinated seeds was counted daily for 21 days after root protrusion. The variables analyzed were: water content, germination, normal seedlings, germination speed index, and average germination time. The experimental design was completely randomized, following a $2 \times 7$ factorial scheme (species $\times$ osmotic potential) for each saline source. Water restriction and ionic effect caused by salts favored seed germination and vigor in both species at -0.2 and $-0.4 \mathrm{MPa}$. However, from $-0.8 \mathrm{MPa}$ onwards, germination decreased significantly for both salts. Seeds of C. jamacaru subsp. jamacaru and P. pachycladus subsp. pernambucoensis were tolerant to salt stress since they germinated up to $-0.8 \mathrm{MPa}(\mathrm{NaCl})$ and $-1.2 \mathrm{MPa}$ (KCl). The latter occurred only for P. pachycladus subsp. pernambucoensis.
\end{abstract}

Keywords: Caatinga. Cereus jamacaru. Pilosocereus pachycladus. Salinity. Vigor.

\section{GERMINAÇÃO DE SEMENTES DE CACTÁCEAS SOB ESTRESSE SALINO}

RESUMO - As sementes de cactáceas que ocorrem em florestas tropicais sazonais secas estão sujeitas a múltiplos estresses, a exemplo do estresse salino, que limita a embebição e, consequentemente a germinação. Assim, objetivou-se comparar o desempenho germinativo de sementes de Cereus jamacaru subsp. jamacaru e Pilosocereus pachycladus subsp. pernambucoensis em condições de salinidade. Para isso, utilizou-se soluções de $\mathrm{NaCl}$ e $\mathrm{KCl}$ nos seguintes potenciais osmóticos: 0,0 (controle); -0,2; -0,4; -0,6; -0,8; -1,0 e -1,2 MPa. As sementes foram colocadas para germinar sob a temperatura de $25{ }^{\circ} \mathrm{C}$ e fotoperíodo de 12 horas. A contagem do número de sementes germinadas foi realizada diariamente durante 21 dias após a protrusão radicular. As variáveis analisadas foram: teor de água, germinação, plântulas normais, índice de velocidade de germinação e tempo médio de germinação. O delineamento foi inteiramente casualizado seguindo o esquema fatorial de $2 \times 7$ (espécie $\times$ potencial osmótico) para cada fonte salina. A restrição hídrica e o efeito iônico causados pelos sais favoreceram a germinação e o vigor das sementes de ambas as espécies nos potenciais osmóticos de $-0,2$ e $-0,4$ $\mathrm{MPa}$, entretanto, a partir de -0,8 MPa houve diminuição expressiva da germinação nos dois sais. As sementes de C. jamacaru subsp. jamacaru e $P$. pachycladus subsp. pernambucoensis foram tolerantes ao estresse salino, pois conseguiram germinar em potenciais de até $-0,8 \mathrm{MPa}(\mathrm{NaCl})$ e $-1,2 \mathrm{MPa}(\mathrm{KCl})$, este último, apenas no caso do $P$. pachycladus subsp. pernambucoensis.

Palavras-chave: Caatinga. Cereus jamacaru. Pilosocereus pachycladus. Salinidade. Vigor.

\footnotetext{
"Corresponding author

${ }^{1}$ Received for publication in 05/31/2020; accepted in 08/12/2021.

${ }^{2}$ Program of Post-Graduation in Agrarian Sciences, Universidade Federal da Paraíba, Bananeiras, PB, Brazil; joaohenriqueconst@gmail.com - ORCID: 0000-0001-6218-5096.

${ }_{3}^{3}$ Department of Agriculture, Universidade Federal da Paraíba, Bananeiras, PB, Brazil; gilvaneide.azeredo@academico.ufpb.br - ORCID: 0000-0001-7823-8260.
} 


\section{INTRODUCTION}

In Brazil, 484 cacti species are found distributed throughout the national territory. Of these, 208 are considered endemic species of Brazilian ecosystems (ZAPPI; TAYLOR, 2020). Mandacaru (Cereus jamacaru DC. subsp. jamacaru) and facheiro (Pilosocereus pachycladus subsp. pernambucoensis [Ritter] Zappi) are two columnar cacti widely occurring in the Caatinga biome, and their seeds can germinate in low water availability soils, which are found in arid and semi-arid areas (SILVA; AZERÊDO; TARGINO, 2020). Despite their wide distribution in the Brazilian semi-arid, seeds of these two xerophilic species are subject to several environmental factors that can influence recruitment of new individuals in their original populations.

In semiarid regions, salts tend to accumulate in soil solution due to a set of factors such as climatic, edaphic, and soil management practices. Excess salts cause several disturbances in plant metabolism, the first of which is osmotic effect restricting water transport in plant tissue, affecting germinability, seedling establishment, plant growth, and development, either by an osmotic imbalance or ionic toxicity (IBRAHIM, 2016; TAIZ et al., 2017; SANTOS et al., 2019).

Germination conditioning of Cactaceae seeds to saline stress is one of the most neglected topics, considering all studies in different research lines related to seed germination of this botanical family, with only 14 taxa having been studied on the subject so far (BARRIOS et al., 2020). In Brazil, a few studies have evaluated seed germination response to salinity conditions of some native cactus species such as Cereus jamacaru subsp. jamacaru (MEIADO et al., 2010), Pilosocereus arrabidae (MARTINS et al., 2012), Pilosocereus catingicola subsp. salvadorensis (LIMA; MEIADO, 2017), Discocactus bahiensis, D. zehntneri subsp. petrhalfarii, D. zehntneri subsp. zehntneri (NASCIMENTO; MEIADO; SIQUEIRA-FILHO, 2018), and Pilosocereus gounellei subsp. gounellei (= Xiquexique gounellei subsp. gounellei) (LIMA; OLIVEIRA; MEIADO, 2020). These studies pointed out important considerations on seed germination conditioning. However, studies comparing saline stress tolerance between species should be portrayed since soil salinization in the Caatinga can negatively affect colonization dynamics of native plant communities, especially in areas at risk of desertification (SANTOS; SOUZA; CASTRO, 2018).

In the laboratory, some compounds have been successfully used in research work to simulate water and saline stress effects on cacti seedlings and seeds, such as polyethylene glycol (PEG 6000), $\mathrm{NaCl}, \mathrm{KCl}$, $\mathrm{CaCl}_{2}$, and $\mathrm{MgCl}_{2}$ (SILVA; AZERÊDO; TARGINO, 2020; SILVA et al., 2021). Using saline solutions at different osmotic potentials is necessary to obtain data that could be indicators in defining the species tolerance degree to saline conditions (TAIZ et al., 2017), enabling a broader understanding of plant population establishment and exploitation.

Given the ecological and sociocultural relevance of mandacaru and facheiro, studies on their seed ecophysiology are of major importance for conservation programs to ensure survival and propagation in natural environment. Thus, this study aimed to compare the germinative performance of $C$. jamacaru subsp. jamacaru and $P$. pachycladus subsp. pernambucoensis seeds under saline stress conditions induced by $\mathrm{NaCl}$ and $\mathrm{KCl}$ in laboratory.

\section{MATERIAL AND METHODS}

Seeds were collected from ripe fruits of $C$. jamacaru subsp. jamacaru and $P$. pachycladus subsp. pernambucoensis adult individuals from two natural populations. Fruits of $C$. jamacaru subsp. jamacaru were collected in an experimental area of the Instituto Nacional do Semiárido (INSA) in the city of Campina Grande, Paraíba State (Brazil), while $P$. pachycladus subsp. pernambucoensis fruits were collected at the farm of Umburana, in the city of Bananeiras, Paraíba State (Brazil). Table 1 presents a summary of the main edaphoclimatic characteristics in the fruit collection areas. The phytophysiognomy in both areas is characterized as Caatinga forest formation at different ecological succession levels.

Table 1. Main edaphoclimatic characteristics in the areas of $C$. jamacaru subsp. jamacaru and P. pachycladus subsp. pernambucoensis fruit collection (BDMEP, 2021).

\begin{tabular}{cccccc}
\hline Area & Coordinates & $\begin{array}{c}\text { Altitude } \\
(\mathrm{m})\end{array}$ & $\begin{array}{c}\text { Annual average temperature } \\
\left(\text { min-max; }{ }^{\circ} \mathrm{C}\right)\end{array}$ & $\begin{array}{c}\text { Annual average rainfall } \\
(\mathrm{mm})\end{array}$ & Soil \\
\hline Campina Grande, $\mathrm{PB}$ & $\begin{array}{c}7^{\circ} 13^{\prime} 50^{\prime \prime} \mathrm{S} \\
35^{\circ} 52^{\prime} 52^{\prime \prime} \mathrm{W}\end{array}$ & 546 & $23.5(28.8-20.2)$ & 777 & $\begin{array}{c}\text { Litholic Neosol } \\
\text { C. jamacaru subsp. } \\
\text { jamacaru }\end{array}$ \\
$\begin{array}{c}06^{\circ} 45^{\prime} 00^{\prime \prime} \mathrm{S} \\
35^{\circ} 37^{\prime} 00^{\prime \prime} \mathrm{W}\end{array}$ & 552 & $22.3(27.8-18.8)$ & 1.188 & $\begin{array}{c}\text { Red-yellow } \\
\text { Oxisol pachycladus subsp. } \\
\text { Bananeiras, } \mathrm{PB}\end{array}$ \\
\hline
\end{tabular}


To identify specimens, plant parts with botanical descriptors were collected, dehydrated in an air circulation oven at $65{ }^{\circ} \mathrm{C}$ for 48 hours, and then herborized. Once made, the exsiccates were sent to the Center for Agricultural Sciences (CCA) "Herbarium Jayme Coelho de Moraes" (EAN/ UFPB) for identification through comparisons with materials of the herbarium collection and specialized literature. The synonymy and spelling of taxa were updated by consulting the database "Lista de Espécies da Flora do Brasil" (REFLORA, 2020).

Fruits were pulped in the Seed Technology Laboratory of the Human, Social and Agrarian Sciences Center of the Federal University of Paraíba, Campus III, Bananeiras, PB. Seeds were separated from funicular pulp by maceration on a sieve, followed by washing in running water. Then, the seeds were left to dry for three days on paper sheets placed on the lab bench. Afterwards, they were kept in paper packaging at room temperature $\left(24 \pm 2{ }^{\circ} \mathrm{C}\right.$; $70 \% \mathrm{RH})$ in the laboratory until the beginning of the experiment, one week after fruit processing.

Seeds were not previously sterilized. Then, to simulate saline stress, salt solutions of sodium chloride $(\mathrm{NaCl})$ and potassium chloride $(\mathrm{KCl})$ were used, in the following osmotic potentials: 0.0 (distilled water), $-0.2,-0.4,-0.6,-0.8,-1.0$, and -1.2 $\mathrm{MPa}$, according to the Van't Hoff equation (SALISBURY; ROSS, 1991). Seeds of both species were placed to germinate in transparent acrylic boxes $(11 \times 11 \times 3.5 \mathrm{~cm})$. Previously sterilized blotting paper was used as substrate. The paper was moistened once with saline solutions at 2.5 times its dry weight, placing two sheets under and one on the seeds. Then, the boxes were kept in a germination chamber at $25{ }^{\circ} \mathrm{C}$ and 12-hour photoperiod (MEIADO et al., 2010).

The number of germinated seeds was counted daily for 21 days, using as germination criterion the emission of radicle. Seed were considered germinated when the radicle tip protruded $\geq 1 \mathrm{~mm}$ out of the operculum opening. The variables analyzed were: seed moisture content, germination percentage, normal seedlings, germination speed index, and average germination time (KRZYZANOWSKI et al., 2020). Seed water content was determined by the oven method at $105 \pm 2{ }^{\circ} \mathrm{C}$ for 24 hours (BRASIL, 2009). Normal seedlings were considered as those with welldeveloped and healthy essential structures, without signs of injuries or deformities.

The statistical design used was completely randomized, following a $2 \times 7$ factorial arrangement (species $\mathrm{x}$ osmotic potential) for each salt type, with four 50-seed replications $(n=200$ seeds per treatment). Statistical analyses were processed using ESTAT/Jaboticabal $^{\circledR}$ and Microcal Origin ${ }^{\circledR} 6.0$ software. Data were subjected to variance analysis by the F-test; then, means compared by the Tukey's test $(p \leq 0.05)$. As interactions were significant, polynomial equations were adjusted. However, due to the occurrence of negative estimates for some characteristics, data were analyzed using the Origin ${ }^{\circledR}$ 6.0 software by the non-linear logistic model (Pôrto et al., 2006), whose model adopted was Logistics 1 (Equation 1): $\quad y=\frac{a}{1+e^{-k(x-x c)}}$, where in: $\mathrm{y}=$ characteristic value for a given value of $\mathrm{x}$ (osmotic potential); $\mathrm{a}=$ maximum y characteristic value; $\mathrm{k}=$ relative growth rate (in the present case of $y$ reduction); $\mathrm{e}=$ neperian logarithm base; $\mathrm{xc}=\mathrm{x}$ value (osmotic potential) which provides a reduction in the maximum characteristic by $50 \%$, and corresponds to the osmotic potential at curve inflection point.

\section{RESULTS AND DISCUSSION}

The variance analysis findings showed a significant interaction effect between factors for all characteristics evaluated $(p \leq 0.01)$. The isolated factors also had effects $(p \leq 0.01)$ when $\mathrm{NaCl}$ was used. Only the factor species had no significant effect on germination $(\mathrm{G})$ and germination speed index (GSI) for seeds under $\mathrm{KCl}$ salt stress $(p \geq 0.05)$ (Table 2).

During the experiment, C. jamacaru subsp. jamacaru and $P$. pachycladus subsp. pernambucoensis seed water contents were 18 and $12 \%$, respectively, due to recent fruit pulping. According to the literature, water content of freshly collected seeds for some cacti species can range from 6.3 to $23.7 \%$ (CHEIB; GARCIA, 2012; CIVATTI; MARCHI; BELLINTANI, 2015).

Seeds of both $C$. jamacaru subsp. jamacaru and $P$. pachycladus subsp. pernambucoensis obtained high germination percentages up to -0.6 $\mathrm{MPa}(\geq 89 \%)$ when under saline stress induced by $\mathrm{NaCl}$ (Figure 1A). At $-0.8 \mathrm{MPa}$, germination decreased only for $C$. jamacaru subsp. jamacaru seeds, whose percentage was $62 \%$, while for $P$. pachycladus subsp. pernambucoensis it was $92 \%$. At potential $-1.0 \mathrm{MPa}$, germination was only observed for $P$. pachycladus subsp. pernambucoensis seeds, which was equivalent to $2 \%$ (Figure 1A). By analyzing the equations obtained by the model Logistics 1 , maximum germination was reduced by $50 \%$ for $C$. jamacaru subsp. jamacaru and $P$. pachycladus subsp. pernambucoensis seeds at osmotic potentials of -0.82 , and $-0.90 \mathrm{MPa}$, respectively (Figure 1A). In other words, both species were able to produce half of the seedlings with maximum germination value at these potentials; therefore, they could germinate under significant water restriction potentials. 
Table 2. Summary of the variance analysis for germination (G), normal seedlings (NS), germination speed index (GSI), and mean germination time (MGT) of C. jamacaru subsp. jamacaru and P. pachycladus subsp. pernambucoensis seeds submitted to saline stress induced by $\mathrm{NaCl}$ and $\mathrm{KCl}$, following a factorial scheme: species (E) x osmotic potential (P), for each saline source.

\begin{tabular}{|c|c|c|c|c|c|}
\hline \multirow{2}{*}{ Sources of variation } & \multirow{2}{*}{$\mathrm{DF}$} & \multicolumn{4}{|c|}{ Mean squares } \\
\hline & & $\mathrm{G}$ & NS & GSI & MGT \\
\hline \multicolumn{6}{|c|}{$\mathrm{NaCl}$} \\
\hline Species $(\mathrm{S})$ & 1 & $193.1429 * *$ & $236.1607 * *$ & $38.4457 * *$ & $3.2064^{*}$ \\
\hline $\begin{array}{l}\text { Osmotic potential } \\
\qquad(\mathrm{Op})\end{array}$ & 6 & $16001.4762 * *$ & $5958.6131 * *$ & $214.7845^{* *}$ & $59.4304 * *$ \\
\hline $\mathrm{S} \times \mathrm{Op}$ & 6 & $272.1429 * *$ & $301.9940 * *$ & $11.7607^{* *}$ & $85.1227 * *$ \\
\hline Residue & 42 & 6.7619 & 20.4464 & 0.7981 & 0.6051 \\
\hline Average & & 65.3571 & 38.3393 & 6.9571 & 5.2000 \\
\hline $\mathrm{CV}(\%)$ & & 3.97 & 11.79 & 12.84 & 14.95 \\
\hline \multicolumn{6}{|c|}{$\mathrm{KCl}$} \\
\hline Species $(\mathrm{S})$ & 1 & $19.4464^{\mathrm{ns}}$ & $391.1429 * *$ & $0.5111^{\mathrm{ns}}$ & $181.0802 * *$ \\
\hline $\begin{array}{l}\text { Osmotic potential } \\
\qquad(\mathrm{Op})\end{array}$ & 6 & $13526.5774 * *$ & $4744.9048 * *$ & $262.4309^{* *}$ & $38.9956^{* *}$ \\
\hline $\mathrm{S} \times \mathrm{Op}$ & 6 & $260.8631^{* *}$ & $397.4762 * *$ & $6.7974 * *$ & $103.9698 * *$ \\
\hline Residue & 42 & 7.0893 & 22.9524 & 0.6549 & 0.8888 \\
\hline Average & & 68.3036 & 40.2857 & 7.3795 & 6.2518 \\
\hline $\mathrm{CV}(\%)$ & & 3.89 & 11.89 & 10.96 & 15.07 \\
\hline
\end{tabular}

**, * significant at $1 \%$ and $5 \%$ probability by the F-test, respectively. ${ }^{\mathrm{ns}}$ - non-significant.

Mandacaru $=95.56 /\left(1+\mathrm{e}^{26.97(\mathrm{x}-0.82)}\right) \mathrm{R}^{2}=0.99$

Facheiro $=94.00 /\left(1+\mathrm{e}^{37.11(\mathrm{x}-0.90)}\right) \quad \mathrm{R}^{2}=0.90$

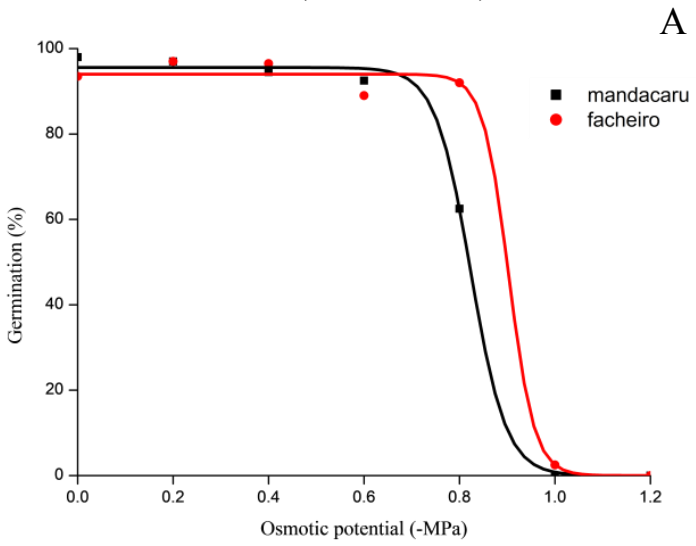

Mandacaru $=97.25 /\left(1+\mathrm{e}^{46.52(\mathrm{x}-0.83)}\right) \mathrm{R}^{2}=0.99$

Facheiro $=91.0595+51.3392 \mathrm{x}-101.9345 \mathrm{x}^{2} \mathrm{R}^{2}=0.91$

B

Figure 1. Germination percentage of mandacaru (Cereus jamacaru DC. subsp. jamacaru) and facheiro [Pilosocereus pachycladus subsp. pernambucoensis (F. Ritter) Zappi] seeds under saline stress induced by $\mathrm{NaCl}(\mathrm{A})$ and $\mathrm{KCl}(\mathrm{B})$.

When comparing species in $\mathrm{KCl}$ solution, both had germination rates above $80 \%$ up to -0.8 $\mathrm{MPa}$. However, at more negative potentials (i.e., -1.0 and $-1.2 \mathrm{MPa})$, only $P$. pachycladus subsp. pernambucoensis seeds germinated (about 22 and $12 \%$, respectively), whose data fitted a quadratic model (Figure 1B). However, although $P$. pachycladus subsp. pernambucoensis shows higher tolerance to saline stress than does C. jamacaru subsp. jamacaru, it is not enough to ensure survival of regenerating individuals in natural habitats. Recent studies have pointed out a reduction in the spatial distribution of $P$. pachycladus subsp. pernambucoensis, while increases in $C$. jamacaru subsp. jamacaru are predicted in future climate change scenarios (CARVALHO et al., 2021).

According to the literature, soil salinity has significant effects on Cactaceae seed germination. High salt levels, mainly sodium chloride $(\mathrm{NaCl})$, are reported to inhibit germination by osmotic potential reduction, harming further germination stages. As in our study, salinity negative effect on germination of native cactus seeds can also be observed in other studies with Pilosocereus arrabidae (MARTINS et al., 2012), Pilosocereus catingicola subsp. salvadorensis (LIMA; MEIADO, 2017), Discocactus 
bahiensis, D. zehntneri subsp. petr-halfarii, D. zehntneri subsp. zehntneri (NASCIMENTO; MEIADO; SIQUEIRA-FILHO, 2018), and Pilosocereus gounellei subsp. gounellei (= Xiquexique gounellei subsp. gounellei) (LIMA; OLIVEIRA; MEIADO, 2020). These studies showed reductions in germination percentage as $\mathrm{NaCl}$ concentrations increased in solutions.

In our study, $\mathrm{NaCl}$ had more deleterious effects than $\mathrm{KCl}$ on germination, mainly for P. pachycladus subsp. pernambucoensis. For Brown et al. (2016), ease of electron withdrawing from atoms or ions has great impact on chemical behavior of substances due to ionization. This is the minimum amount of energy required to remove an electron from an atom or ion valence shells. In other words, as $\mathrm{Na}$ has a higher ionization energy than does $\mathrm{K}$, seeds may have spent more energy for cation absorption during germination (SILVA et al., 2021). Another explanation could be the use of $\mathrm{K}$ as a cofactor in more than 40 enzymes, as well as for cell turgor establishment and electroneutrality maintenance (TAIZ et al., 2017).

As for normal seedling percentage (NS), saline stress by $\mathrm{NaCl}$ had no significant effect on $C$. jamacaru subsp. jamacaru seeds up to $-0.4 \mathrm{MPa}$ (68\%), decreasing therefrom. Yet for P. pachycladus subsp. pernambucoensis, the regression equation showed no effect of salt stress up to $-0.8 \mathrm{MPa}(48 \%)$, falling to zero therefrom for both species. The osmotic potentials that provided $50 \%$ of the maximum NS were $-0.74 \mathrm{MPa}$ for $C$. jamacaru subsp. jamacaru and $-0.84 \mathrm{MPa}$ for $P$. pachycladus subsp. pernambucoensis (Figure 2A).

Conversely, on germination medium containing $\mathrm{KCl}$, the potential providing $50 \%$ of the maximum NS was $-0.84 \mathrm{MPa}$ for $C$. jamacaru subsp. jamacaru and $-0.92 \mathrm{MPa}$ for P. pachycladus subsp. pernambucoensis. NS percentages decreased for $C$. jamacaru subsp. jamacaru as potentials reduced, while for $P$. pachycladus subsp. pernambucoensis, the highest NS percentages were obtained at -0.4 and $-0.6 \mathrm{MPa}$, which was $67 \%$ for both (Figure 2B). Some cacti species may have their germination favored when subjected to $-0.2,-0.4 \mathrm{MPa}$, or even $0.6 \mathrm{MPa}$, but generally decrease significantly at potentials below $-0.6 \mathrm{MPa}$, and hence the appearance of normal seedlings (BARRIOS et al., 2020).
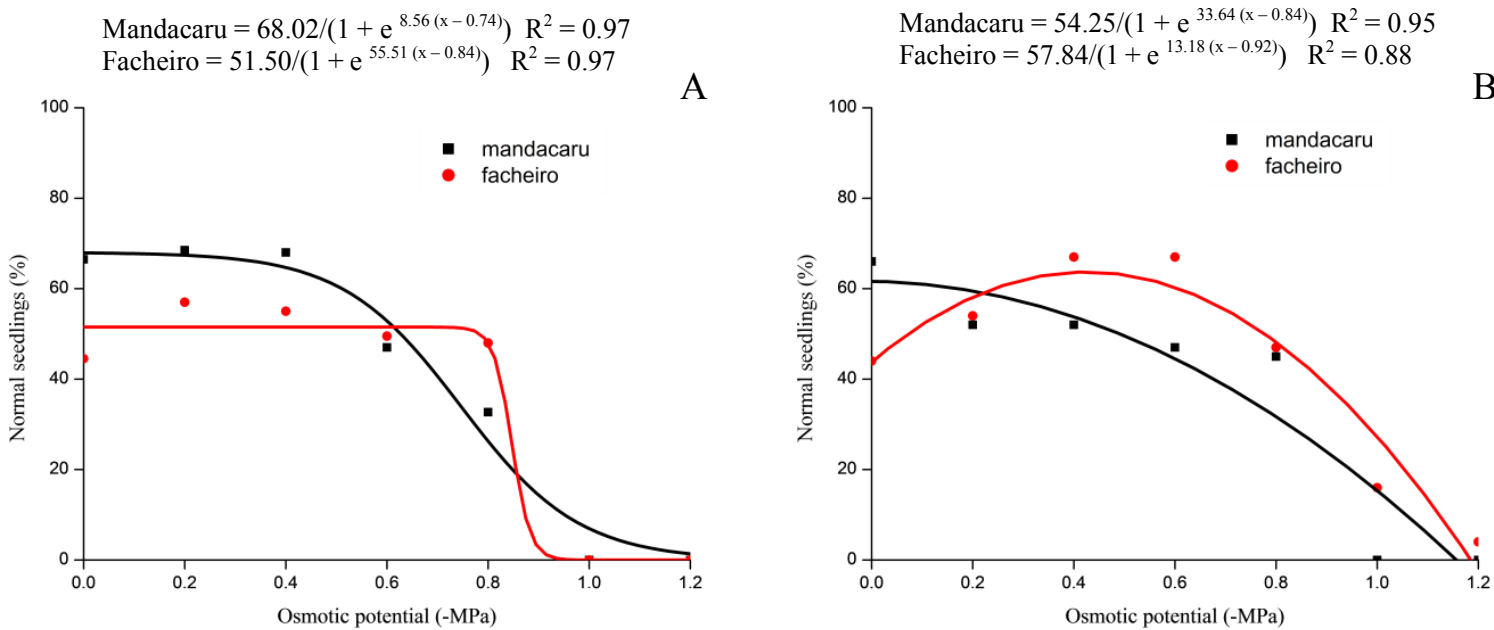

Figure 2. Percentage of normal seedlings of mandacaru (Cereus jamacaru DC. subsp. jamacaru) and facheiro (Pilosocereus pachycladus [F. Ritter] subsp. pernambucoensis [F. Ritter] Zappi) under saline stress induced by $\mathrm{NaCl}(\mathrm{A})$ and $\mathrm{KCl}(\mathrm{B})$.

Our findings showed that more negative osmotic potentials (e.g., $-0.8,-1.0$, and $-1.2 \mathrm{MPa}$ ) tend to promote the appearance of abnormal seedlings, whose main characteristics were stunted root systems and tegument attachment to hypocotyl. Silva, Azerêdo, and Targino (2020) also observed the appearance of abnormal seedlings for $C$. jamacaru subsp. jamacaru and $P$. pachycladus subsp. pernambucoensis seeds subjected to water stress by PEG 6000 solutions, especially at -0.6 and $-0.8 \mathrm{MPa}$. According to these authors, osmotic potential reductions on germination medium decrease the viability and vigor of $C$. jamacaru subsp. jamacaru and $P$. pachycladus subsp. pernambucoensis seeds.

Salinity delays or prevents seed germination as it reduces potential gradient between soil and seed surface, restricting water uptake reserve mobilization by seeds. However, under high salt concentrations, ions are absorbed and accumulate in seed tissues, causing protein denaturation and membrane destabilization, with $\mathrm{Na}^{+}$being a more potent denaturant than $\mathrm{K}^{+}$(IBRAHIM, 2016; TAIZ et al., 
2017). Thus, the lower the osmotic potential, the lower the respiratory rate and energy production for germination process (FARIAS et al., 2009).

When analyzing germination speed index (GSI), the potentials promoting $50 \%$ of the maximum GSI were -0.51 and $-0.84 \mathrm{MPa}$ for $C$. jamacaru subsp. jamacaru and $P$. pachycladus subsp. pernambucoensis, respectively, for seeds under saline stress by $\mathrm{NaCl}$ (Figure 3A).

As for saline stress by $\mathrm{KCl}, 50 \%$ of the maximum GSI was observed at $-0.60 \mathrm{MPa}$ for $C$. jamacaru subsp. jamacaru and $-0.74 \mathrm{MPa}$ for $P$. pachycladus subsp. pernambucoensis (Figure 3B). Our results showed that $P$. pachycladus subsp. pernambucoensis seeds were more tolerant to saline stress when compared to $C$. jamacaru subsp. jamacaru seeds on both mediums (Figures 3A and 3B). Furthermore, GSI at $-0.2 \mathrm{MPa}$ was similar or even superior to that of control, both for C. jamacaru subsp. jamacaru and $P$. pachycladus subsp. pernambucoensis. Therefore, at low concentrations, salinity can stimulate seed germination of both plant species. Such a germinal response to saline stress may explain, among other factors, wide distribution of both species in Caatinga areas, as these characteristics show an adaptation to semi-arid regions, making them advantageous in these environments. $\begin{array}{ll}\text { Mandacaru }=14.20 /\left(1+\mathrm{e}^{4.72(\mathrm{x}-0.51)}\right) & \mathrm{R}^{2}=0.97 \\ \text { Facheiro }=11.25 /\left(1+\mathrm{e}^{31.60(\mathrm{x}-0.84)}\right) & \mathrm{R}^{2}=0.97\end{array}$

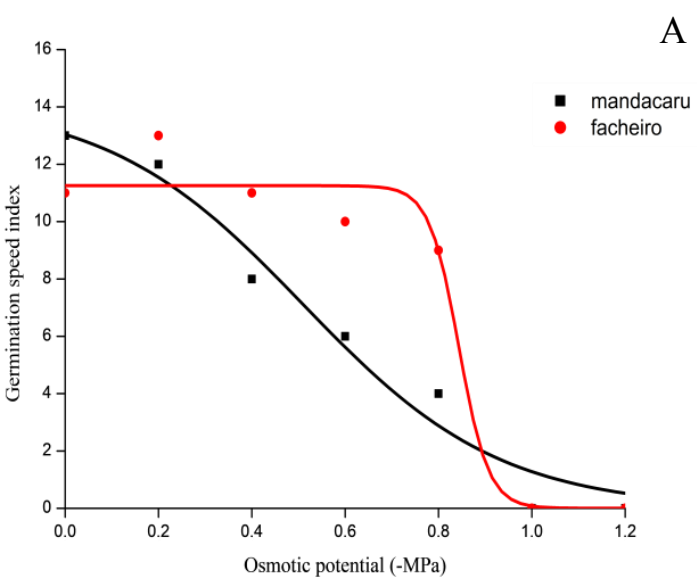

Mandacaru $=14.45 /\left(1+\mathrm{e}^{8.03(\mathrm{x}-0.60)}\right) \mathrm{R}^{2}=0.96$ Facheiro $=11.90 /\left(1+\mathrm{e}^{8.21(\mathrm{x}-0.74)}\right) \quad \mathrm{R}^{2}=0.98$

B

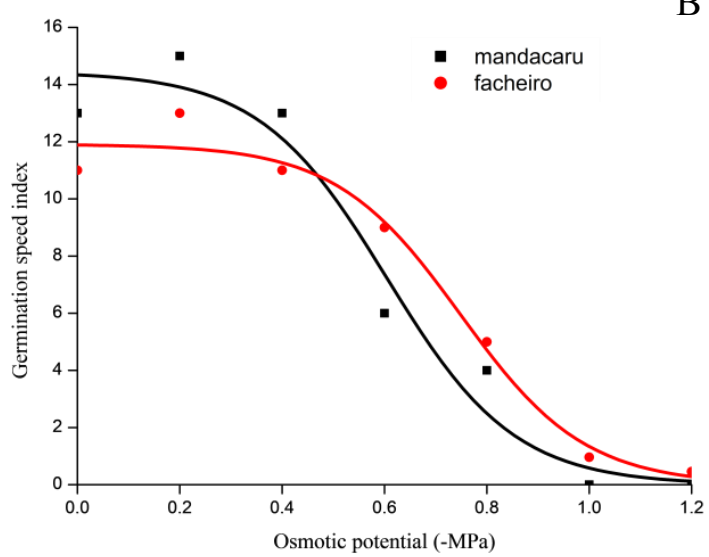

Figure 3. Germination speed index of mandacaru (Cereus jamacaru DC. subsp. jamacaru) and facheiro (Pilosocereus pachycladus [F. Ritter] subsp. pernambucoensis [F. Ritter] Zappi) seeds under saline stress induced by $\mathrm{NaCl}(\mathrm{A})$ and $\mathrm{KCl}$ (B).

Regarding mean germination time (MGT), although estimates were negative for the quadratic equation, except for $P$. pachycladus subsp. pernambucoensis in $\mathrm{KCl}$ (Figure 4B), data did not fit the Logistics equation 1 adopted for the other variables. Therefore, we opted for the quadratic equation. Seeds of $C$. jamacaru subsp. jamacaru and $P$. pachycladus subsp. pernambucoensis from the control treatment took about four days to germinate. However, MGT increased as osmotic potentials decreased, except for those potentials at which no germination occurred (Figures 4A and 4B).

Seeds of $C$. jamacaru subsp. jamacaru subjected to saline stress by $\mathrm{NaCl}$ took from four days (control) to 10 days $(-0.8 \mathrm{MPa})$ to germinate (Figure 4A), while $P$. pachycladus subsp. pernambucoensis seeds took on average five days for the radicle to emerge at the same potential $(-0.8$ MPa). However, $P$. pachycladus subsp. pernambucoensis seeds submitted to $-1.0 \mathrm{MPa}$ took \pm 14 days to emit the radicle, that is, about 3.5 times longer than the control (Figure 4A). When analyzing germination performance, $P$. pachycladus subsp. pernambucoensis seeds under stress by $\mathrm{KCl}$ at -1.0 and -1.2 MPa had the highest MGT values, which were equivalent to 13 and 14 days, respectively (Figure 4B). Yet for C. jamacaru subsp. jamacaru seeds, the highest MGT values were observed at -0.6 and $-0.8 \mathrm{MPa}$, which were around 8 and 9 days, respectively (Figure 4B). Therefore, under saline stress conditions, MGT lasts longer, hindering the emergence of seedlings. 
Mandacaru $=3.0048+20.3589 \mathrm{x}-19.6756 \mathrm{x}^{2} \mathrm{R}^{2}=0.64$ Facheiro $=2.6037+12.6683 \mathrm{x}-9.1093 \mathrm{x}^{2} \mathrm{R}^{2}=0.12$

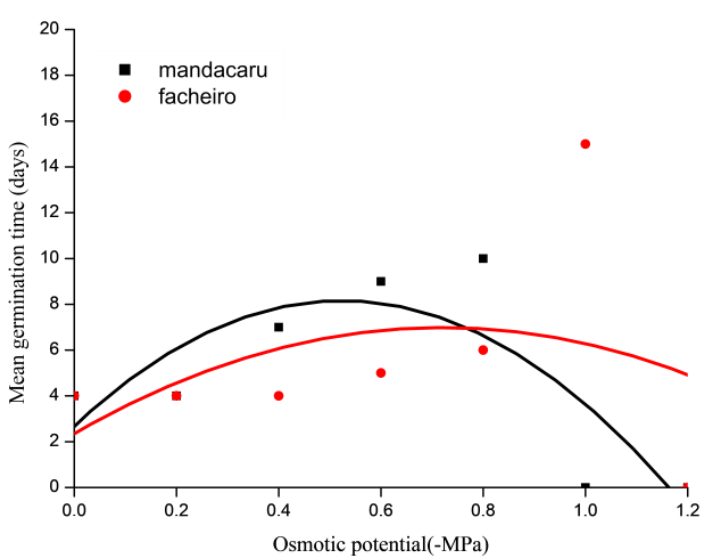

Mandacaru $=2.4242+18.5749 \mathrm{x}-17.4668 \mathrm{x}^{2} \mathrm{R}^{2}=0.48$ Facheiro $=3.8702+0.1473 \mathrm{x}-7.9627 \mathrm{x}^{2} \mathrm{R}^{2}=0.98$

A

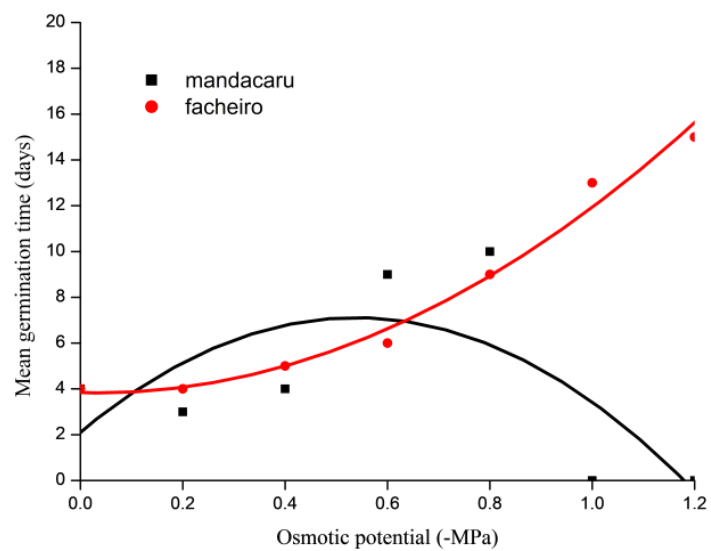

Figure 4. Mean germination time of mandacaru (Cereus jamacaru DC. subsp. jamacaru) and facheiro (Pilosocereus pachycladus [F. Ritter] subsp. pernambucoensis [F. Ritter] Zappi) seeds under saline stress induced by $\mathrm{NaCl}(\mathrm{A})$ and $\mathrm{KCl}$ (B).

Time and space germination distribution is an interesting ecophysiological aspect for plant seeds, as it increases recruitment of regenerating individuals when under favorable environmental conditions (SOUZA, 2020). Although valuable, our findings do not express the real tolerance of C. jamacaru subsp. jamacaru and $P$. pachycladus subsp. pernambucoensis seeds to saline stress in natural environments. This is because, under field conditions, seeds are subject to a cascade of barely perceptible or measurable events, which influence germination and establishment of plant populations in the habitat, such as interaction between one or more abiotic factors, water deficit, light incidence, surface temperature, among others (MEIADO et al., 2016; OLIVEIRA et al., 2017; SILVA; AZERÊDO; TARGINO, 2020). Thus, studies on germination behavior of Cactaceae seeds occurring in the Caatinga, such as C. jamacaru subsp. jamacaru and P. pachycladus subsp. pernambucoensis, should be encouraged to understand establishment and chances of survival of these species in their natural environment and, above all, in climate change and anthropic intervention scenarios. In short, conservation programs must take this information into account to ensure resilience and preservation of these populations in their occupation sites.

\section{CONCLUSIONS}

Seeds of $C$. jamacaru subsp. jamacaru and $P$. pachycladus subsp. pernambucoensis are tolerant to saline stress since they can germinate and form normal seedlings under water deficit up to $-0.8 \mathrm{MPa}$ $(\mathrm{NaCl})$ and $-1.2 \mathrm{MPa}(\mathrm{KCl})$, the latter only for $P$. pachycladus subsp. pernambucoensis.

Osmotic potentials equal to or less than -1.0
MPa inhibit C. jamacaru subsp. jamacaru seed germination of the population studied, either in $\mathrm{NaCl}$ or $\mathrm{KCl}$ solutions.

Seeds of $P$. pachycladus subsp. pernambucoensis are more tolerant to saline stress when compared to $C$. jamacaru subsp. jamacaru seeds.

The osmotic effect of both salts can favor germination and vigor of $C$. jamacaru subsp. jamacaru and $P$. pachycladus subsp. pernambucoensis seeds at potentials such as -0.2 and $-0.4 \mathrm{MPa}$.

$\mathrm{NaCl}$ is more deleterious than $\mathrm{KCl}$, especially for $P$. pachycladus subsp. pernambucoensis.

\section{REFERENCES}

BARRIOS, D. et al. Seed traits and germination in the Cactaceae family: A review across Americas. Botanical Sciences, 98: 417-440, 2020.

BDMEP - Banco de dados meteorológicos para ensino e pesquisa. Instituto Nacional de Meteorologia. Ministério da Agricultura, Pecuária e Abastecimento. 2021. Disponível em: <http:// www.inmet.gov.br/portal/index.php?r=bdmep/ bdmep>. Acesso em: 17 mai. 2021.

BRASIL. Ministério da Agricultura, Pecuária e Abastecimento. Regras para análise de sementes. Brasília, DF: MAPA; ACS, 2009. 399 p.

BROWN, T. L. et al. Química: a ciência central. 13. ed. São Paulo, SP: Pearson Education do Brasil, 2016. 1216 p.

CARVALHO, T. K. N. et al. Cereus jamacaru DC. 
and Pilosocereus pachycladus F. Ritter (Cactaceae) in the Northeast region of Brazil: future perspectives and distribution. Revista Brasileira de Geografia Física, 14: 126-134, 2021

CHEIB, A. L.; GARCIA, Q. S. Longevity and germination ecology of seeds of endemic Cactaceae species from high-altitude sites in south-eastern Brazil. Seed Science Research, 22: 45-53, 2012.

CIVATTI, L. M.; MARCHI, M. N. G.; BELLINTANI, M. C. Conservação de sementes de cactos com potencial ornamental armazenadas sob diferentes condições de umidade e temperatura. Gaia Scientia, 9: 17-26, 2015.

FARIAS, S. G. G. et al. Efeitos dos estresses hídrico e salino na germinação de sementes de gliricídia [Gliricidia sepium (JACQ.) STEUD.]. Revista Caatinga, 22: 152-157, 2009.

IBRAHIM, E. A. Seed priming to alleviate salinity stress in germinating seeds. Journal of Plant Physiology, 192: 38-46, 2016.

KRZYZANOWSKI, C. F. et al. Vigor de sementes: conceitos e testes. 2. ed. Londrina, PR: ABRATES, 2020. $601 \mathrm{p}$.

LIMA, A. T.; MEIADO, M. V. Discontinuous hydration alters seed germination under stress of two populations of cactus that occur in different ecosystems in Northeast Brazil. Seed Science Research, 27: 292-302, 2017.

LIMA, A. T.; OLIVEIRA, B. A.; MEIADO, M. V. Gibberellic acid provides greater tolerance to saline stress in cactus seed germination. Communications in Plant Sciences, 10: 80-84, 2020.

MARTINS, L. S. T. et al. Seed germination of Pilosocereus arrabidae (Cactaceae) from a semiarid region of south $\square$ east Brazil. Plant Species Biology, 27: 191-200, 2012.

MEIADO, M. V. et al. Effects of light and temperature on seed germination of cacti of Brazilian ecosystems. Plant Species Biology, 31: 87-97, 2016.

MEIADO, M. V. et al. Seed germination responses of Cereus jamacaru DC. ssp. jamacaru (Cactaceae) to environmental factors. Plant Species Biology, 25: 120-128, 2010.

NASCIMENTO, J. P. B.; MEIADO, M. V; SIQUEIRA-FILHO, J. Á. Seed germination of three endangered subspecies of Discocactus Pfeiff. (Cactaceae) in response to environmental factors.
Journal of Seed Science, 40: 253-262, 2018.

OLIVEIRA, D. M. et al. O aumento da temperatura reduz a tolerância ao estresse hídrico na germinação de sementes de Pereskia grandifolia Haw. subsp. grandifolia (Cactaceae)? Gaia Scientia, 11: 26-36, 2017.

PÔRTO, D. R. Q. et al. Acúmulo de macronutrientes pela cebola 'Optima' estabelecida por semeadura direta. Horticultura Brasileira, 24: 470-475, 2006.

REFLORA - Plantas do Brasil: resgate histórico e herbário virtual para o conhecimento e conservação da flora brasileira. Rio de Janeiro: Instituto de Pesquisas Jardim Botânico do Rio de Janeiro. Flora do Brasil 2020 - Algas, Fungos e Plantas. 2020. Disponível em: <http://floradobrasil.jbrj.gov.br/ reflora/listaBrasil/ConsultaPublicaUC/

ConsultaPublicaUC.do\#CondicaoTaxonCP $>$. Acesso em: 16 mai. 2021.

SALISBURY, F. B.; ROSS, C. W. Plant physiology. 4 ed. Belmont: Wadworth, 1991. 682 p.

SANTOS, A. M.; SOUZA, R. F.; CASTRO, F. C. Auto-organização da vegetação de caatinga em áreas salinizadas no município de Petrolina-PE. Scientia Plena, 14:1-12, 2018.

SANTOS, D. G. et al. Crescimento e clorofila em mudas de noni irrigadas com água salina em substrato com vermicomposto. Revista Brasileira de Engenharia Agrícola e Ambiental, 23: 586-590, 2019 .

SILVA, J. H. C. S.; AZERÊDO, G. A.; TARGINO, V. A. Resposta germinativa de sementes de cactáceas colunares sob diferentes regimes de temperatura e de potencial hídrico. Scientia Plena, 16: 1-13, 2020.

SILVA, J. H. C. S. et al. Water restriction in seeds of Cereus jamacaru DC. Revista Brasileira de Ciências Agrárias, 16: e8431, 2021.

SOUZA, D. D. Adaptações de plantas da Caatinga. São Paulo, SP: Oficina de Textos, 2020. $96 \mathrm{p}$.

TAIZ, L. et al. Fisiologia e desenvolvimento vegetal. 6.ed. Porto Alegre, RS: Artmed, 2017. 858 p.

ZAPPI, D.; TAYLOR, N. P. Cactaceae in flora do Brasil 2020. Jardim Botânico do Rio de Janeiro. 2020. Disponível em: <http:// floradobrasil.jbrj.gov.br/reflora/floradobrasil/FB70>. Acesso em: 16 mai. 2021. 